\title{
\$sciendo
}

\begin{abstract}
Alina Kaszkur
Kazimierz Wielki University in Bydgoszcz

\section{URBAN LAB AS A TOOL FOR JOINT MANAGEMENT IN CITIES}

DOI: $10.2478 /$ ppsr-2020-0014

\begin{abstract}
Author
Alina Kaszkur is an Assistant Professor of Political Science in the Department of Theory of Politics and Public Sphere Management at the Faculty of Political Science and Administration, Kazimierz Wielki University in Bydgoszcz. Her main research focuses are innovation in the public sphere, political participation and urban policy.

ORCID no. 0000-0003-0845-2186

e-mail: alina.kaszkur@ukw.edu.pl

Abstract

The Urban Lab concept is aimed at creating innovations and expanding citizens' participation in decision-making processes. This article presents the main premises of this concept, the specifics of its implementation in the conditions of Polish cities, the structure, objectives and types of activities of Urban Labs as well as functions they may perform in stimulating cooperation of the city with enterprises, scientific institutions and non-governmental organisations.
\end{abstract}

Keywords: Urban Lab, urban governance, Urban Lab Gdynia, Urban Lab Rzeszów

\section{Introduction}

Efficient management is one of the primary challenges that modern cities have to face. The complexity of problems the local administration has to deal with (demographic and economic crises, climate changes, social problems) determines the necessity of searching not only for innovative modes of solving them, but also for new management models. In this context, in Polish cities the growing popularity of participatory instruments has also come to be a valid trend in the development of management practices.

If a city wishes to develop in a sustainable mode, its residents need to be involved in this process. The use of the potential inherent in such cooperation offers benefits to both the city and its residents. For the authorities and the local administration, the residents' knowledge and experience is a valuable resource in optimisation of the municipal offer. Such dialogue serves as a foundation for building more efficient systems of satisfying social needs. Any initiatives aimed at including residents in decision-making and management processes also reinforce the sense of responsibility for common issues, forming a significant impulse for the residents to act for the sake of the community and to care for its interests and welfare. In effect, activities of this type are conducive to implementing a vision of a well-organised, accessible and useful city that meets the needs and expectations of its inhabitants. 
However, projects of local authorities focused on engaging the residents in city issues are not always successful. Practice shows that even if cooperation with individual groups goes smoothly, joint activities that involve multiple entities still pose a challenge. However, it is precisely such an extensive forum of cooperation in which all key stakeholders participate, bringing in their knowledge, experiences, attributes and resources that can offer a potential for creating innovative, locally applicable solutions and a way to face future challenges. In order to improve the efficiency of their activities in this respect, authorities of many European cities are increasingly willing to try experiments such as urban laboratories. These experiments are given various names and forms of operation, and they are either limited to activities focused on selected fragments of the municipal reality or become a tool used to co-manage the city as a whole. In Poland, this trend took the form of is the innovative Urban Lab concept, implemented as an urban programme, whose model of functioning significantly differs from the laboratory formulas already tried in the country.

Urban Lab is an implementation experiment that comprises a tool for cooperation of the city with enterprises, scientific entities and non-governmental organisations; it also aims at improving the residents' quality of life. It is to be compliant with the smart city idea via innovative solutions for the identified problems and by generating added value with the use of urban resources. The Urban Lab concept may refer to the study methodology, to a specific venue within the city space, and to an innovative environment in which solutions used by the city residents can be designed, tested, implemented and monitored (Urban Lab-Projekt MIiR). This is a venue for meetings, consultations and negotiations, drafting municipal policies, generating innovations and setting up a network of connections among stakeholders. The dimension of relations of this type is reflected in the Quadruple Helix model (Carayannis and Campbell 2009) oriented at fostering conditions for optimal cooperation among the users engaged in the process of creating innovations, i.e. public authorities, universities, enterprises and the civic society.

The purpose of this article is to present the concept of an Urban Lab that is adapted to the conditions of Polish cities. The author also attempts to answer the following questions: What is the specific nature of Urban Lab implementation in Polish cities? What is the structure of Urban Labs adapted to Polish conditions? What are the aims and character of Urban Lab activities? What can be their role in stimulating development and cooperation in a city?

The analysis was carried out on the basis of source materials and reference books. The article also discusses the examples of Urban Lab implementation in the cities of Gdynia and Rzeszów, the cities selected for a pilot project involving the adaptation of the Urban Lab conception to the conditions of Polish cities.

\section{Urban Labs}

An urban laboratory is an umbrella term for various methodological and conceptual approaches that tackle the complexity of urban areas, promoting new platforms for experiments, citizen inclusion and cooperation (Scholl et al 2017, 10). Such diversity is also reflected in the names of individual laboratory types envisioned by the guidelines developed by the international Urb@Exp team, whereas their profiles of operation are often similar to each other. One such option is a Change Lab-a systemic and participation-based 
initiative, characterised by a creative approach to complex social challenges, supporting transformation of the entire system via potential intervention approaches (ibidem: 11). In a Change Lab, a diverse group of leaders from different parts of a poorly performing societal system act jointly to improve it and make it innovative (Hassan and Bojer 2005, 5). On the other hand, the name "Design Lab" encompasses such forms as a Gov Lab, an Innovation Lab, a Policy Lab or a DESIS (Design for Social Innovation and Sustainability) Lab. The activities of such labs go beyond the established practice, often making use of a project-based approach. They focus primarily on sustainable development and innovations in management. Impact Labs are targeted at learning and initiating cooperation with partners from the public and private sectors to solve strategic problems. Living Labs, which are participatory platforms for open innovation, represent a user-oriented approach that actively engages residents in the innovation creation process. On the other hand, Makerspaces (or FabLabs) are workshops whose resources may be used for the realisation of users' own projects; they are venues for learning and use of advanced technologies to cultivate innovations. Reality Labs are places where specific solutions (mainly related to sustainable development issues) are tested in real conditions. Social Innovation Labs (or Social Living Labs) focus on system changes by experimenting with social innovations. On the other hand, City Labs are participation platforms where the local authorities together with other stakeholders jointly attempt to learn new modes of handling urban challenges and financially support initiatives of this type. As indicated by researchers engaged in the URB@Exp project, Lab-like initiatives are frequently implemented by communes, though not necessarily under the names listed above. Their distinguishing traits include focus on residents, and on discovering and implementing new forms of collaboration and governance (Scholl et al 2017, 11-13).

Adapted to Polish conditions, the Urban Lab concept is an instrument of cooperation between local authorities and residents (including social organisations), companies and scientific entities. Urban Lab is an organisation, an office space and/or a part of the city chosen for experimenting with innovative solutions (initiating, testing, implementing and evaluating projects), which uses the city's resources to generate extra values. The primary goals of Urban Lab include: cooperation with partners aimed at discovering solutions for diagnosed urban problems; providing access to municipal data that can be used to create innovations and to implement Urban Lab's projects; the operation of Urban Café, a physical venue for meetings and debates; operation of Innovation Incubator supporting the process of preparation of innovative projects submitted by the residents (Urban Lab Rzeszów). The activities of Urban Lab may also focus on the use of smart technology or the management of urban space.

The operation of Urban Lab relies on a city office and on dialogue and cooperation with the city's residents. The objective of the adopted model of cooperation and a broad range of activities is to guarantee a complex approach to challenges faced by cities, and to develop efficient solutions to current problems. The purpose the of activities aimed at creating public values is to establish long-term relations among the entities participating in processes initiated by Urban Lab.

The attempt at characterising the Urban Lab initiative presented above is by no means exhaustive, given the fact that the concept is adapted to the conditions and needs of a specific city, and thence the scope and the object of the laboratory's activities may be very 
extensive. However, at its core lies the focus on creating innovations, based on cooperation among local authorities, universities, companies and representatives of civic society.

This type of cooperation is reflected in the Quadruple Helix model (Carayannis and Campbell 2009). It is an extension of the Triple Helix model that comprises scientific centres, enterprises and the government (including local governments). The network relationships within the Triple Helix are changing the participating institutions into relatively autonomous yet interdependent spheres (Leydesdorff and Etzkowitz 2001). The quality of their mutual relations determines the processes related to the creation of knowledge and innovations. The Quadruple Helix model is an effect of adding an additional helix, namely the civic society, as an equally important creator and participant of innovative solutions, whose involvement may produce more welcomed innovations by re-orienting research and development toward public preferences (Schütz, Heidingsfelder and Schraudner 2019, 131). In the Urban Lab concept, building relations on the basis of the Quadruple Helix model is initiated by the local authorities, tasked with setting up a platform for the exchange of knowledge and experiences and with including the individual helices in innovative processes.

The realisation of the Urban Lab concept in Poland is in its initial phase because the pilot implementation takes place only in two cities. The principles of the functioning of such laboratory are discussed later in this paper.

Figure 1. Urban Lab

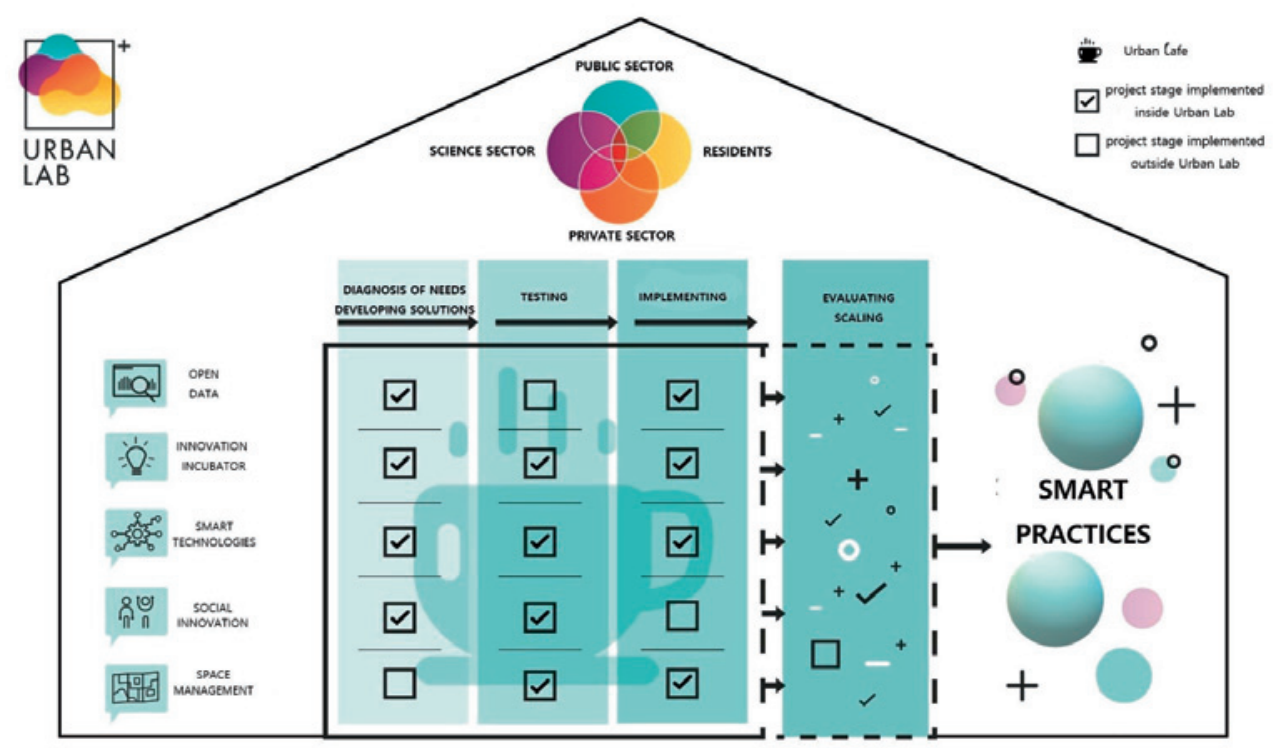

Source: Institute of Urban and Regional Development. Available at <http://smartcity-expert.eu/urban-lab-od-miejskiej-idei-do-jej-wdrozenia/?fbclid=IwAR2ZkyvphX_tWdFD10pzE8aL7kq5acMOuHviEGgXfWU2-TOqtfIMPjPXdSs> [Accessed 15.05.2020].

\section{Urban Lab Gdynia}

In terms of the development of public participation and innovativeness, Gdynia stands out among Polish cities due to the long-term policy of the city authorities that has focused on development with active support of the residents. Gdynia authorities have a specific 
conception of city development that is consequently implemented and supported by appropriate institutions, as proven by the facts that the City Hall structure includes the office of the Deputy Mayor for Innovations, and that the Social Innovation Laboratory (a budget entity of Gdynia Municipality in charge of developing and supporting innovative social solutions addressed to the city inhabitants) is an active and dynamic institution. Furthermore, authorities are open to new initiatives that have the potential to provide residents with even better opportunities to actively participate in the life of the city and introduce changes.

In 2019, Gdynia inaugurated the implementation of pilot adaptation of the Urban Lab concept in the conditions of Polish cities. The project is co-financed by the Ministry of Investment and Development from EU funds. ${ }^{1}$ Urban Lab is an instrument of the city's cooperation with enterprises, scientific entities and non-governmental organisations. The formula of its operation relies on the identification of socially important problems and the search for innovative solutions. In consequence, the implementation of the programme is aimed at improving the city residents' quality of life (Oficjalny start Urban Lab w Gdyni).

Gdynia Urban Lab functions within the structure of the Social Innovation Laboratory. It is not only a method of work but also an actual meeting venue in the city-a workshop and conference space - created as an environment conducive for creation and testing of innovative solutions that improve the residents' quality of life. The structure of Urban Lab is made up of the Strategic Group, which is responsible for setting out the directions of its activities. Every year, a thematic area is selected that is important in the context of the city's problems and challenges. The Strategic Group is composed of experts on city development and the representatives of the City Office and its authorities. Its tasks include the evaluation of all activities contained in the lab programme. Another entity operating as part of Urban Lab is the Thematic Team. It consists of persons with substantial experience in the thematic area, which determines the profile of operation of the Urban Lab in a given period. Appointed by the city mayor for a one-year term, the Team has no more than thirteen members representing various stakeholder groups: the city administration, the city council, district councils and non-governmental organisations. The Team performs an advisory function and is authorised to offer recommendations on problematic areas and development challenges set out by the Strategic Group. Its tasks also include operationalisation of those recommendations as well as evaluation of the solutions developed and tested in Urban Lab (Regulamin zespołu tematycznego Urban Labu). By a decision of the Thematic Team, the Innovation Incubator may be launched; it is an entity focused on actions on a much smaller scale, used to create ad hoc solutions particularly important for specific groups of residents. As part of the Incubator's activities, social innovators receive support in the form of trainings or consultations, and selected solutions are supported financially. The Thematic Team may also appoint interdisciplinary working groups whose task is to prepare systemic solutions for specific problems of the city.

1 The Urban Lab concept, prepared in theory in the Institute of Urban and Regional Development and developed as part of the project entitled "Urban Lab as a pilot tool to improve the quality of urban residents' life in accordance with the smart city idea”, received financial support from the Ministry of Investment and Development from the Technical Support Programme for years 2014-2020 (Cohesion Fund). In the case of Gdynia, the amount of co-financing is PLN 3,084,000.00. (Project: "Application of the Urban Lab concept in Gdynia"). 
The first Thematic Team appointed as part of Gdynia Urban Lab focused on the development of civic society and participation. Apart from being a platform for meetings of expert groups, Urban Lab has also provided an area for discussion and debate for residents: Urban Café. This is also a venue where educational programmes, trainings, lectures, workshops, film screenings, literary meetings, consultations or fairs can take place. A majority of these events are prepared in line with the needs and interests expressed by the residents and the municipal officials. The first year of Urban Lab's operation was marked by a number of meetings devoted to broadly understood urban issues, e.g. civic society, participation, urban psychology, senior policy, climate changes, public spaces or food-sharing. As part of the Innovation Incubator path, Urban Lab has also prepared the Urban Competence Programme for the city's residents, which is devoted to the development of the civic society and to expanding the problem solving potential of the local communities. On the one hand, the Programme is aimed at increasing competence and expanding awareness about the determinants of actions undertaken in the city; on the other hand, it delivers educational-type content, spreading knowledge about the operation of various entities in the city as well as the forms of civic dialogue. Furthermore, it also has a practical dimension, fostering the development of ideas for municipal innovations (Regulamin naboru do Programu Kompetencji Miejskich UrbanLab Gdynia). Another project, City Ideas, is a participation tool relying on the principle of subsidiarity; within its framework, a call for projects for social micro-innovations is issued in one of Urban Lab's priority areas selected for the given edition. The ideas that receive positive evaluation from the expert commission are submitted for further testing (Regulamin naboru Pomysłów na Miasto UrbanLab Gdyni). Therefore, the project also offers an opportunity for implementation of ideas which did not receive a sufficient number of votes to be financed by the civic budget.

\section{Urban Lab Rzeszów}

Apart from Gdynia, another place where a pilot Urban Lab project was launched in 2019 is Rzeszów, ${ }^{2}$ a city whose authorities for years have attempted to implement consistently a specific conception of development. Rzeszów aspires to become an intelligent, ecological city, and so far it has achieved numerous successes in this area.

In Rzeszów, Urban Lab is a project implemented directly by the officials of the Rzeszów City Office, and it is both a methodology and a physical venue in the city. Its functioning is similar to Gdynia Urban Lab. The Lab's operation focuses on areas such as cooperation with partners looking for solutions to diagnose urban problems; issues related to the open-access database providing information useful in the search for solutions to improve life in the city; space for development and creation of innovative solutions, i.e. Urban Café and the Innovation Incubator; and support for the incubation process for innovative ideas pertaining to the solutions for urban problems (Otwarcie Urban Lab Rzeszów). Within the structure of Rzeszów Urban Lab there is also the Strategic Group, established by the mayor of Rzeszów, which consists of representatives of local government, scientists, experts from NGOs and business organisations, and decision-makers from the most important local administration divisions that are involved in a project that is the focus of

2 PLN 3.5 million was assigned for project implementation in Rzeszów, where EU co-financing is PLN 2.6 million. 
the Laboratory's activity in a given year. Rzeszów Urban Lab also includes two Thematic Teams. Its physical venue in the city centre, equipped with conference rooms and offering a space for the meetings of residents, is Urban Café. To ensure efficient performance of the Urban Lab project in Rzeszów, the city office quickly launched the Open Data website. The major thematic areas chosen for the first stage of operation of Rzeszów Urban Lab were the implementation of solutions used for making city data available to the residents and issues related to transport and electro-mobility, in line with the guidelines of the Strategic Group. These issues are also handled by the Thematic Teams.

The main task of Urban Lab is to involve various groups of residents in making changes to the city-thus a large number of these initiatives focus in particular on seniors, children and persons with disabilities. Through initiatives such as "Hackathon Mobility", engineers, programmers, graphic designers, website designers and programming enthusiasts have become involved in developing useful solutions for Rzeszów in the area of eco-mobility and alternative forms of transport (Urban Lab Rzeszów - Facebook).

The activities of Urban Lab in Rzeszów-aimed at dialogue and building cooperation with residents - also focus on the educational programmes, conferences and workshops. Furthermore, the space of Urban Café offers the possibility for city officials to meet with residents and present their own needs and ideas for the city (Urban Lab-miejskie laboratorium otwarte!).

Urban Lab Rzeszów opened its second year with a call for ideas for urban innovations in the area of smart living. This action was a part of the operation of Rzeszów Startup Urban Accelerator. Selected concepts of micro-innovations in three areas-modern and resident-friendly urban space, mobility-facilitating solutions for the city and development of urban green areas - will be tested in the urban space, with the option of later implementation (Masz pomysł na innowacje w Rzeszowie? Zgłoś go do Urban Lab). These types of competitions or online meetings focused on specific topics are examples of initiatives launched by Urban Lab Rzeszów. Their goals are not only to involve the residents in city-related issues but also to enhance their urban competences.

\section{Recapitulation}

In compliance with urban governance theory, the primary role of municipal authorities is to coordinate activities in the entire local territory with the aim of accomplishing joint objectives (Edelenbos and van Dijk 2017). At the same time, inclusion of various entities in decision-making processes, the necessity of negotiations and consensus building require the application of tools that can rise to such challenges most comprehensively. Therefore, striving for an increased efficiency of management, local authorities are opening up to innovative solutions in this respect, which is exemplified by an attempt to introduce the idea of urban laboratories in Polish conditions.

Gdynia and Rzeszów stand out among Polish cities. Based on their previous successes in increasing innovativeness and participation, both cities had to present their respective visions of adapting the Urban Lab concept before the start of the project. Their participation undoubtedly was the result of their earlier experiences in this field, and selecting them certainly limited the risk of failure of the experiment. However, at the time when this article is written, we cannot judge how urban laboratories would work in other cities where participation levels are significantly lower. 
As to the actual implementation of the concept, it turned out to be similar in both cases; the differences stem mainly from the direction of policies already implemented by the local governments as well as the current issues and challenges Gdynia and Rzeszów are facing. Urban laboratories may have very diverse forms, sometimes with universities or NGOs acting as leaders. In Poland, local self-government institutions take this role; considering their capability to involve residents and use their potential effectively, it seems to be an optimal solution at present.

The Urban Lab concept is aimed both at expanding the citizens' share in decision-making processes and at creating innovations, improving the quality of life and contributing to the city's development. Thanks to the merger of the complementary potential of the public, private, social and science sectors, the city acquires resources for generating comprehensive, sustainable and widely accepted solutions.

With such broad representation, the local authorities are able to identify social needs and expectations in a more precise manner when drafting municipal policies and programmes. Simultaneously, the civil society can act as a two-way channel, including feedback about the nature and performance of public policies and the need for any changes. Good urban governance enhances the involvement of communities and various sectors of society in government affairs, which contributes to democratic decision-making (Rashid 2011, 212).

It is also worth noting that by creating a friendly space for cooperation and negotiation, Urban Labs also streamline communication among the officials and citizens. Furthermore, the presence of representatives of various local administration units in the laboratories facilitates better communication and coordination of activities among the city office institutions and employees.

Based on the experiences related to implementing the pilot programmes in both cities, preliminary conclusions can be drawn. The residents were interested in the project; however, as the coordinators of the project point out, what becomes a challenge during the project implementation is how to convince the municipal officials that Urban Lab is a tool that can bring them real benefits. Strengthening cooperation between the city hall branches may not only improve the efficiency of their functioning, but also facilitate the discharge of the officials' duties as well as offer new possibilities (16: Urban Lab-czyli jak współtworzyć swoje miasto?). This is true also for other participants as the success of the idea of urban laboratories depends on the quality and the depth of individual stakeholders' involvement.

Many questions regarding the nature, methods and effectiveness of Urban Lab still remain unanswered. Without doubt, this tool has the potential to improve the quality of life in cities, whereas the good practices developed so far within this framework also evidence that by putting the knowledge and the resources at the disposal of their residents, cities may independently control the processes of stimulating innovativeness, becoming thus an inspiration for other municipalities.

The attempt at characterising the Urban Lab concept in this paper may also provide useful information for researchers working on further development of this idea and for representatives of local authorities and local administration interested in its implementation. 


\section{References}

16: Urban Lab-czyli jak współtworzyć swoje miasto?. Urbcast-podcast o miastach. Available at https://anchor.fm/urbcast/episodes/16-Urban-Lab---czyli-jak-wsptworzyswoje-miasto--go-kordynatorzy-Urban-Lab-ejb2kes [Accessed 09.09.2020].

Carayannis E.G. and Campbell D.F.J. (2009), “Mode3" and "Quadruple Helix": Toward a 21st century fractal ecoinnovation system'. Journal of Technology Management. Vol. 46, No. $3 / 4$.

Edelenbos J. and van Dijk M.P. (2017). Chapter 1: Introduction: Urban governance in the Realm of Complexity. Available at 〈https://www.researchgate.net/publication/313885257_CHAPTER_1_Introduction_Urban_governance_in_the_Realm_of_ Complexity> [Accessed 17.04.2020].

Hassan Z. and Bojer M. (eds.) (2005). The Change Lab Fieldbook, p. 5. Available at «http:// social-labs.org/wp-content/uploads/2014/12/Generon_Fieldbook_V2.0.pdf> [Accessed 15.03.2020].

Idea Urban Lab - dlaczego Laboratorium Miejskie potrzebuje stałego dostępu do informacji? Available at https://whiteaster.com/blog/idea-urban-lab-dlaczego-laboratorium-miejskie-potrzebuje-stalego-dostepu-do-informacji/s [Accessed 25.03 2020].

Leydesdorff L. and Etzkowitz H. (2001). 'The Transformation Of University-industry-government Relations'. Electronic Journal of Sociology. No. 5(4). Available at «ttp://www. sociology.org/content/vol005.004/th.html> [Accessed 15.03.2020].

Masz pomysł na innowacje w Rzeszowie? Zgłoś go do Urban Lab. Available at «https:// www.resinet.pl/aktualnosci/rzeszow/masz-pomysl-na-innowacje-w-rzeszowie-zglosgo-do-urban-lab.html> [Accessed 15.10.2020].

Oficjalny start Urban Lab w Gdyni. Available at 〈https://www.popt.gov.pl/strony/wiadomosci/oficjalny-start-urban-lab-w-gdyni/> [Accessed 17.03.2020].

Otwarcie Urban Lab Rzeszów. Available at https://otwartedane.erzeszow.pl/articles/otwarcie-urban-lab-rzeszow〉 [Accessed 17.03.2020].

Rashid A. A. (2011). Urban governance, management and finance, The State of Asian Cities 2010/11. UN-Habitat, p. 212. Available at «http://www.rrojasdatabank.info/citiesasian1011-06.pdf> [Accessed 17.04.2020].

Scholl Ch. et. all (eds) (2017). Guidelines for Urban Labs, pp. 10-13. Available at «https:// www.maastrichtuniversity.nl/research/institutes/msi/research-output/guidelines-urban-labs> [Accessed 15.03.2020].

Schütz F., Heidingsfelder M. L. and Schraudner M. (2019). 'Co-shaping the Future in Quadruple Helix Innovation Systems: Uncovering Public Preferences toward Participatory Research and Innovation'. She Ji: The Journal of Design, Economics, and Innovation. Vol. 5, No. 2, p. 131.

Regulamin naboru do Programu Kompetencji Miejskich UrbanLab Gdynia w obszarze rozwoju społeczeństwa obywatelskiego oraz zwiększania potencjału społeczności lokalnych do rozwiązywania problemów, Załącznik nr 1 do Zarządzenia nr 36/2019 Dyrektora Laboratorium Innowacji Społecznych z dn. 3.12.2019 zm. Zarządzeniem Nr 37/2019 Dyrektora Laboratorium Innowacji Społecznych z dn. 23.12.2019. 
Regulamin naboru Pomysłów na Miasto UrbanLab Gdynia w obszarze rozwoju społeczeństwa obywatelskiego oraz zwiększania potencjału społeczności lokalnych do rozwiązywania problemów, Załącznik nr 1 do Zarządzenia nr 8/2020 Dyrektora Laboratorium Innowacji Społecznych z dn. 11.02.2020.

Regulamin zespołu tematycznego Urban Labu Gdynia do spraw rozwoju społeczeństwa obywatelskiego i partycypacji, Załącznik Nr 1 do Zarządzenia Nr 1033/19/VIII/R Prezydenta Miasta Gdyni z dnia 13.06.2019 r.

UrbanLab - co takiego tworzymy w Gdyni. Available at «http://lis.gdynia.pl/2019/05/09/ urbanlab-co-takiego-tworzymy-w-gdyni/> [Accessed 15.03.2020].

UrbanLab Gdynia. Available at https://www.facebook.com/UrbanLabGdynia/〉 [Accessed 15.03.2020].

UrbanLab Gdynia czeka na Twój pomysł na miasto. Available at «https://lis.gdynia.pl/urbanlab-gdynia-czeka-na-twoj-pomysl-na-miasto/s [Accessed 15.03.2020].

Urban Lab - miejskie laboratorium otwarte! Przyjdź z pomysłem i ulepsz Rzeszów. Available at https://rzeszow-news.pl/urban-lab-czyli-miejskie-laboratorium-otwarte-przyjdz-z-pomyslem-i-ulepsz-rzeszow/> [Accessed 15.03.2020].

Urban Lab - od miejskiej idei do jej wdrożenia. Available at <http://smartcity-expert.eu/ urban-lab-od-miejskiej-idei-do-jej-wdrozenia/?fbclid=IwAR2ZkyvphX_tWdFD10pzE8aL7kq5acMOuHviEGgXfWU2-TOqtfIMPjPXdSs> [Accessed 15.05.2020].

Urban Lab - Projekt MIiR. Available at 〈http://irmir.pl/urbanlab/〉 [Accessed 15.03.2020]. Urban Lab Rzeszów-Facebook, Available at https://www.facebook.com/UrbanLabRzeszow> [Accessed 15.10.2020].

Urban Lab Rzeszów. Available at 〈https://www.erzeszow.pl/46-innowacje/15642-urbanlab-rzeszow.html > [Accessed 15.03.2020]. 